\title{
Revisiting Electoral Violence in Zimbabwe: Problems and Prospects
}

\author{
Happy Mathew Tirivangasi ${ }^{1}$, Louis Nyahunda ${ }^{1, *}$ and Tafadzwa Clementine Maramura ${ }^{2}$ \\ ${ }^{1}$ Department of Research Administration and Development, University of Limpopo, P. bag X1106, Sovenga, \\ 0727, South Africa \\ ${ }^{2}$ Department of Public Administration, University of Fort Hare, Faculty of Management and Commerce, South \\ Africa
}

\begin{abstract}
This study explores theoretical contradictions with realism, regarding the actors or perpetrators of violence when explaining the causes of electoral violence in the Zimbabwean context. These perspectives can be divided into two contesting schools of thought. The first group is mainly made up of rational theories and holds the position that, autocratic governments use electoral violence as a way of influencing electoral outcome. The second position suggests that the weaker political party is the one responsible for electoral violence. This paper then, contributes to the ongoing debate on the causes of electoral violence by advancing the notion that electoral violence should not be seen based on one position but from a multifaceted position. This is because, neither of the two theoretical approaches are wrong but what differs is the context. This paper argues that the idealism of holding one position hinders policy analysis to electoral violence, monitoring and observing election process as it places either, the ruling party or the opposition party as a unit of analysis.
\end{abstract}

Keywords: Electoral violence, Authoritarian, Democracy, Stakeholder Engagement Theory, Zimbabwe.

\section{INTRODUCTION}

In the post-colonial era, elections have become a huge feature of the new democracies since the early1990s (Lindberg (2007). The end of cold war marked the third wave of democratisation, which in turn saw the introduction of the multiparty elections and the end of authoritarian regimes in some countries (Huntington, 1991). Elections are widely regarded as an institutional instrument at the heart of western democracies (Collier-\& Vicente, 2011; Tirivangasi et al. 2020). They have served different purposes. For instance, they are used as a legitimate way of transferring political power from one political party to the other or political leader to the other within one constituency (Birch \& Muchlinski, 2017). In other words, politicians competitively battle for votes in order to legitimately assume office of power. Hoglund (2009) notes that the idea of assuming power through elections would make politicians to be more accountable to their citizens. Collier and Vicente (2011) observe that countries which follow the soviet style of leadership are regarded as deficient as they lack an acceptable form of exchanging power. In a bid to build legitimate governments, multiparty election system had to be spread to the other parts of the world, for instance, the newly born states in the Sub Saharan Africa. The intention was to end the autocracies which had spread across the world as result of socialist influences.

*Address correspondence to this author at the University of Limpopo, South Africa, Tel +27 15268 2401; E-mail: nyahundalouis@gmail.com

E-ISSN: 1929-4409/21
Elections were supposed to serve as a peaceful way of transferring power, instead of war or violence against political opponents. However, this is successful in a situation where all the political players have accepted the rules of the game. In most autocratic neopatrimonialism regimes, the incumbent leaders have used violence to influence the outcome of the elections (Collier \& Vicente, 2012; Wallswort, 2015). In sub-Saharan Africa, Burchard (2015) notes that almost all elections with few exceptions have been marked with violence. Hoglund (2009) agrees with the above observation, as he notes that each year people lose their lives during the election period. The price of democracy is high, as elections results in the loss of human life, economic and state failure, destruction of property and damage to societal human relations. Citizens also lose their trust in the democratic system (Mapuva, 2010; Birch \& Muchlinski, 2017).

This study explores theoretical contradictions with reality in regard to the actors or perpetrators of violence when explaining the causes of electoral violence in the Zimbabwean context. These perspectives can be divided into two contesting schools of thought. The first group comprising of mostly rational theories argue that autocratic governments use electoral violence as a way of influencing electoral outcome (Bhasin \& Ghandi, 2013; Taylor, Pevehouse \& Straus, 2017). The other position suggests that the weaker political party is the one responsible for electoral violence, a view mostly advanced by (Collier \& Vicente, 2008). This paper contributes to the ongoing debate on the causes of electoral violence by advancing a notion that electoral 
violence should not be seen based on one position but from a multifaceted position. This is because, neither of the two theoretical approaches are wrong but what differs is the context. We argue that the idealism of holding a position hinders policy analysis to electoral violence, monitoring and observing election process as it places either, the ruling party or the opposition party as a unit of analysis. The study used political stakeholder engagement theory to study the causes of electoral violence in Zimbabwe.

\section{RATIONALE OF THE STUDY}

The history of elections in Zimbabwe have been marked with electoral violence resulting in the government battling with both internal and external legitimacy. The winning party only attains legitimacy (in liberal democracies) when elections are carried out in a free and fair environment, absent of violence in all its forms. In contrast, elections in Zimbabwe have been marked with violence since the early 2000 up to the recent elections in 2018 and yet, the empirical review of literature shows that research on electoral violence has received less attention over the years (Hoglund, 2009; Taylor, Pevehouse \& Straus, 2017; Birch \& Muchlinski, 2017). The electoral studies on Zimbabwe have used her to discuss strategies of authoritarian regimes during elections (Hoglund, 2009; Bhasin \& Ghandi, 2013) and further, Collier and Vicente (2012) and Chuturved (2005) have used the country to motivate their theoretical models on electoral violence. However, none of the scholars have looked at other actors apart from the state as potential sources of violence. Neither was the theory of weak actor being perpetrators of violence is sufficient to explain electoral violence. The current study seeks to identify the causes of electoral violence in Zimbabwe, looking at different actors as the potential sources of violence.

\section{REVIEW OF LITERATURE}

\section{Conceptualisation of Electoral Violence}

There is no uniform definition of the concept, electoral violence among the scholars as each has their own conceptualisation. However, we can draw conclusions from how scholars have defined the concept over the years. This study reviewed several works which were influential in the development of this concept (Fischer, 2002; Wilkinson, 2004; Straus \&, Taylor, 2012; Birch \& Muchlinski, 2017; Akwei, 2018). It is from these typical definitions that I decided to conceptualise electoral violence to capture the meaning relevant to this study. The words coercive and manipulation featured in most of these definitions. In light of this, this study, defines electoral violence as the violent (physical, structural or psychological), coercive or systematic passive acts by political actors before, during and after the election to influence the election outcome. This definition considers the actions of all the political actors before, during and after the elections. It does not wade off from what studies have focused on. Our intention is for this concept to capture the motive and timing of the electoral violence by political actors. We also understood that these are organised acts which can constitute structural violence, we chose to call these passive acts, the inaction of a political party on matters regarding violence, when its apparent that all members of different political parties may be involved. Further, among the political actors' violence is carried out for one to benefit from it, this can occur at any course of the election timeline. However, Birch and Muchlinski (2017) viewed electoral violence as a subtype of electoral fraud, but this study does not delve into issues of fraud or other forms which render elections as not authentic but rather focused on violence on beings.

\section{Types of Electoral Violence}

In order to identify perpetrators of electoral violence in the Zimbabwean context, it is important to identify "who-did-what-to-whom" during the elections period. This will help in the analysis of the causes of electoral violence as we will be able to identify the actors involved in the electoral violence. In the same vein with how we conceptualised electoral violence, this study is interested in electoral violence perpetrated against human beings not property. The word coercive was a constant feature, a coercive action can happen at any stage of the electoral process (Birch \& Muchlinski, 2017), that is the pre-election, during and after election. The study by the two scholars reveal three characteristics which epitomise this phenomenon, namely, "a) a perpetrator, b) a victim, and c) an action that varies in intensity." (Birch \& Muchlinski, 2017, p.5). In this case, all incidents analysed in this study will utilise the examples by Birch and Muchlinski (2017) in identifying the actors, victims as well as the severity of the actions undertaken. In order to disclose different stakeholders involved in orchestrating electoral violence, Birch and Muchlinski (2017) gives examples of electoral violence by type as shown in Table 1.

\section{THE THEORETICAL APPROACHES TO ELEC- TORAL VIOLENCE DEBATE}

The theoretical explanation of electoral violence stem from the existing theories of ethnic conflict, civil 
Table 1: Examples of Electoral Violence by Type

\begin{tabular}{|c|c|c|}
\hline & Threats & Attacks \\
\hline State-on-nonstate & $\begin{array}{l}\text { Government threatens to use military force against } \\
\text { protestors. } \\
\text { Military surrounds polling places in opposition } \\
\text { neighborhoods. }\end{array}$ & $\begin{array}{l}\text { Police beat voters at polling } \\
\text { stations. } \\
\text { State security forces assault opposition } \\
\text { candidates. }\end{array}$ \\
\hline Nonstate-on-state & $\begin{array}{l}\text { Terrorists threaten to bomb polling stations. } \\
\text { Militias issue statements threatening to carry out } \\
\text { attacks on voters. }\end{array}$ & $\begin{array}{l}\text { Terrorists threaten to bomb polling stations. } \\
\text { Opposition partisans attack military and } \\
\text { police forces. }\end{array}$ \\
\hline Nonstate-on- nonstate & $\begin{array}{c}\text { Ethnic group } \mathrm{X} \text { threatens to } \\
\text { attack ethnic group } \mathrm{Y} \text {. } \\
\text { Supporters of party A forcibly displace supporters of } \\
\text { party } \mathrm{B} \text {. }\end{array}$ & $\begin{array}{l}\text { Ethnic separatists attack members of the } \\
\text { government. } \\
\text { Campaign rallies by activists supporting } \\
\text { opposing parties turn violent. }\end{array}$ \\
\hline $\begin{array}{l}\text { International actor on neighbouring } \\
\text { state }\end{array}$ & $\begin{array}{c}\text { The government threatens to expel international } \\
\text { election observers. }\end{array}$ & $\begin{array}{l}\text { Foreign military exchange fire with the state } \\
\text { military. } \\
\text { Transnational criminal groups or } \\
\text { insurgencies attack election facilities. } \\
\text { Ethnic militias attack election observers }\end{array}$ \\
\hline
\end{tabular}

Source: (Birch \& Muchlinski, 2017: 221).

war and state suppression. However, the paper adopted stakeholder theoretical perspective borrowed from business studies. Firstly, it will discuss the electoral authoritarianism theoretical perspective. This theory emerges from the ongoing debate on non-fully democratic elections in Africa which are run by autocratic leaders. Schedler (2010), a critical scholar in this field states that electoral authoritarian regimes are those [regimes like Zimbabwe] which hold elections like the democratic western states on all levels of the government, but still violate the rules of the game when it comes to elections. Lindberg (2007) notes that multiparty elections are a critical part of the democratic process which has the cost and benefits.

Lindberg (2007) argues that eventually the autocratic states will reach the liberal democratic state which is currently enjoyed by the western states, and electoral violence are part of that process. However, Lindberg also agrees that elections can be used as a way of sustaining the leadership of the autocratic leaders. Several authors concur that when the incumbent leader sees that they have a chance of losing the elections they may end up resorting to violence in order to consolidate and retain their power (Schedler, 2010; Collier \& Vincente, 2012). The motivation behind the use of violence is to swing the electoral votes towards the party that is exercising coercive action. Voters end up supporting a violenceprone party to avoid the danger of being attacked or risking their lives (Wantchekon, 1999).

This theory is highly contested by the one that holds that, the likelihood of violence to occur is due to the existence of a weak political party that is only strong when it comes to violence (Skaperdas \& Grofman, 1995; Sterck, 2015). This theoretical model is largely advanced by Collier \& Vicente (2008). This position differs from the electoral authoritarian theoretical perspective which suggest that electoral violence is mainly caused by the incumbent government. According to Collier and Vicente (2008), there are at least three strategies which can be used to manipulate the electoral outcome namely: vote buying, vote miscalculating and vote intimidation. In light of the mentioned strategies, Collier and Vicente argue that the incumbent leader can use government resources to buy votes and in turn, they are also much likely to influence or control the actions of the electoral body. This may result in the miscalculation of votes. The authors argued that the only option left for the opposition is the use of violence to contest the outcome of the elections. This is where this theory dwells on, as Collier and Vicente suggest that it is the weak party that would engage in electoral violence. Onapajo (2014) although he explores the weaker party theoretical perspective by (Collier \& Vicente, 2008), he argues that the two authors did not reveal how one would identify the weaker party hence, he categorises the two competing groups as the ruling incumbent leader and the opposition parties.

In regard to these theoretical perspectives, we do not disagree that they are important in explaining the causes of electoral violence. However, this paper argues that electoral violence is multidimensional and viewing it from these viewpoints would make 
government or political parties to be our unit of analysis. This complicates policy making as well as other activities such as monitoring of elections and prevention of electoral violence. In this regard, it argues that the analysis of electoral violence should be seen from a multifaceted approach. This approach would involve looking at the actors mentioned above plus other actors such as "government forces, supporters of the government or opposition groups (in more or less organized forms), spontaneous demonstrators and even rebel groups refusing to be included in the formal political life" (Laakso, 2007:228).

This study will also utilise political stakeholder engagement framework in trying to figure out how to forge way forward and make policy recommendations. The researchers were interested actors who are identified as or potential perpetrators of electoral violence by the previous framework. Political stakeholder engagement theory is propelled by the work of (Jeffree, 2009; Akwei, 2018), which focused on key stakeholders such as political parties and candidates in developing policies to avert violence and intimidation. Although, Akwei's study limited her analysis to key players, the political parties and candidates, in this study we do believe stakeholders may extend beyond the stated in some context. Akwei outlined seven stages in which one can go through using political stakeholder framework in seeking peaceful environment during elections. The stages are outlined in Figure 1 below:

To interpret the stages shown in Figure 1, stage one, the political parties should deliberate on critical issues in regard to the prevention of electoral violence. Akwei (2018) notes that issues should not be limited to vote buying, fraud via excessing corrupt behaviour, hate speech or defamation of character. The second stage, is about understanding the actors involved, taking in consideration the interest and influence of different stakeholders. On the third stage, each stakeholder should understand the dos and don'ts, which are clearly informed by the engagement process. The fourth stage is about information, building trust among the stakeholders. On stage five, the stakeholders through a consultative process should develop realistic solutions and these may involve some sort of trade off which favour progress instead of party agenda. According to Jeffrey (2009), the sixth stage is where parties can develop sustainable actions to

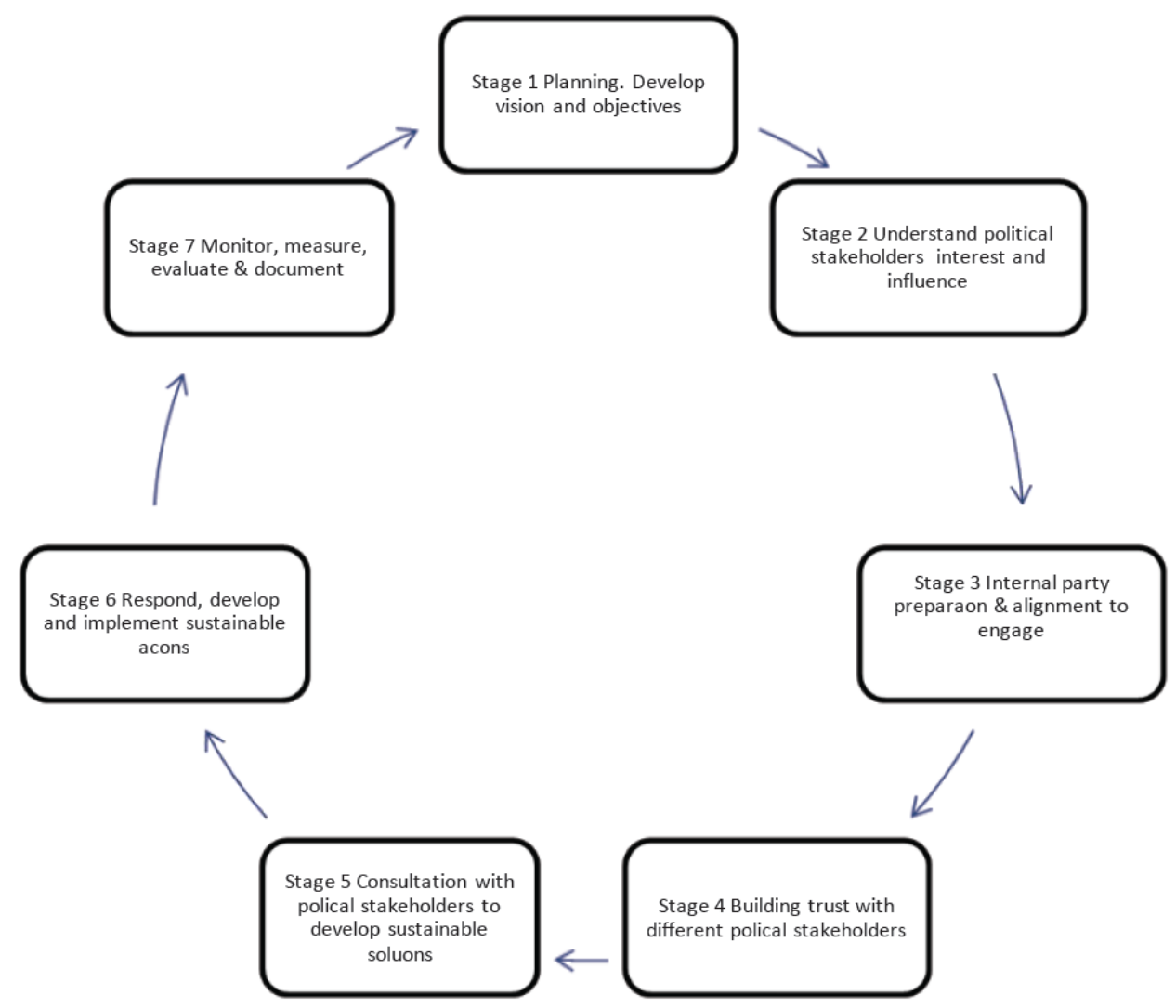

Figure 1: Stages of the Political stakeholder engagement Process.

Source: Jeffrey (2009). 
implement the agreed objectives by all members. The seventh stage will involve monitoring and evaluation of the various commitments made by different stakeholders.

\section{RESEARCH METHODOLOGY}

This is a qualitative desk study research. The researchers utilised different techniques in order to come up with answers to the research questions espoused in this study. In the period between January and March 2019, we searched google scholar data bases: web of science and university of Antwerp institutional repository for articles in the field of political economy, elections, democracy, ethnic and group conflict referencing electoral violence. Table 2 shows the key words used to identify articles. The literature search had an approximately 156 hits which was screened until 48 papers in the disciplines mentioned above were left. Table $\mathbf{2}$ is illustrated below:

Table 2: Keywords and Phrases used to Identify Papers Referencing Electoral Violence Incidence or Electoral Violence

\begin{tabular}{|c|}
\hline Keywords and phrases \\
\hline \hline Electoral violence \\
Elections \\
Zimbabwe \\
Africa \\
Ruling party and electoral violence \\
Political parties and electoral violence \\
Incidences of electoral violence since 1980 \\
Institutions and electoral violence \\
groups and electoral violence \\
Causes of electoral violence \\
Trends of electoral violence \\
\hline
\end{tabular}

Source: Author.

The researchers also used the reference list and bibliographies of the important contributions to identify relevant papers. This method of collecting and searching literature review was very efficient. Furthermore, they made use of sources from Afrobarometre, reports from election observers, books, policy review papers, newspapers and journal articles. Critical Discourse Analyses (CDA) was used to analyse the documents collected. Discourse analysis is an important analytical method when trying to identify power relations and the actors involved. A critical discourse analyst would engage with the literature, interpreting it by discovering the relationship between discourse and reality looking at past and present
(Bondarouk \& Ruel, 2004). The units of analysis include things such as written texts, news information, advertisements, pictures, spoken words, and videos (Bondarouk \& Ruel, 2004).

\section{RESULTS AND DISCUSSION}

The researchers analysed electoral violence in the Zimbabwean context using the categories created by Birch and Muchlinski (2017) to identify examples of actors perpetuating electoral violence and political stakeholder engagement theory. The "who-did-what-towhom" criterion was used in the analysis of the incidents of electoral violence in Zimbabwe as units of analysis. Further, using the examples identified under this criterion, we can identify the actors and the causes behind each incident. The second part of the discussion will be guided by the political stakeholder engagement framework as were commended, with possible ways or approach of preventing electoral violence and set tone for dialogue before and after elections. In the case of Zimbabwe, this paper analysed the electoral reports from 1980- 2018 and picked out relevant case studies to bring out the context of electoral violence and dialogue as the paper unfolds.

\section{The Ruling Party as the Perpetrator of Electoral Violence}

The first type of electoral violence stated under the "who-did-what-to-whom" criteria by Birch \& Muchlinski (2017) is the State-on-nonstate, this is when the incumbent government unleashes the military on the public or the opposition in order to influence the outcome of the elections. This is a popular belief among the political economist and other democracy theorist who attribute the main cause of electoral violence as being a result of autocratic governments who seek to retain power necessary (Collier \& Vicente, 2012; Wallswort, 2015). Kriger (2005) argues that ZANU PF the only party to govern Zimbabwe since independence from the British rule, has used intimidation and violence as strategies to influence the outcomes of elections.

Taylor et al. (2013) concur with these findings as they note that during the 2008 elections, the government unleashed electoral violence and intimidation which held back the opposition supporters from registering and giving the ruling party an advantage. In the post-election, ZANU PF would punish those constituencies who did not vote for them 
in the past election (Kriger, 2005). Bhasin and Gandhi (2013), noted the same thing in their studies, that electoral violence can be unleashed on segments of the society to vote in certain ways (Bhasin \& Gandhi, 2013). The ruling party used two agents to unleash violence over its opponents namely, the war-veterans and youth groups.

\section{The War Veterans}

The study by Kriger (2005) can reveal that the use of war veterans started as early as the 1980s as ZANU PF did not bring all its comrades to the assembly points. His research can reveal that all parties were committed to no violence, however, some of ZANLA's guerrillas stayed behind in areas where they operated during the liberation struggle (Kriger, 2005). Report by Group of Independent British Observers (1980), pointed out that this group of former guerrillas intimated the electorates on behalf of the party (Kriger, 2005). The observations by Group of Independent British Observers will be justified later as role of war veterans working in cohorts with the ZANU PF can be clearly be seen in the elections that followed as this group commit documented electoral violent acts. These include killing and torturing activists and members of the opposition (Human Rights Watch, 2008; US Bureau of Democracy, Human Rights, and Labor, 2009).

\section{ZANU PF Youth Group}

Hodzi (2014) describes the youth in Zimbabwe as highly corruptible and easily used by conniving politicians. ZANU PF militia mostly comprised of unemployed youth was used to terrorise the opposition in Zimbabwe. Makumbe (2002) notes that the war veterans and ZANU PF youth used state resources such as vehicles to go into locations and embark on violence. This supports the notion that the government sponsors violent activities. The study by Makumbe, reveals that ZANU PF government has used the youth to abduct and torture community members (Kagwanja, 2005) and evidence on the ground suggests that most people would not attend the ZANU PF rallies if they were not coerced or risk danger of violence (Makumbe, 2002). Ranger (2002), highlights a clear case study of ZANU Pf prioritising the use of youth for spreading its revolutionary agenda. The ZANU PF led government introduced the Border Gezi youth training camp, where youth were trained to be patriotic using military ethics. This was made compulsory to access most of the government position, the graduates of the programme were deployed throughout the country. These youth groups would inflict violence on MDC party members during the 2002 elections (Ranger, 2002).

\section{The use of Military on Civilians}

According to Birch \& Muchlinski (2017)'s criterion, "who-did-what-to-whom", the state would threaten to use military force. The attacks would manifest with police beating voters at polling stations and the security forces assaulting opposition leaders. The involvement of the army during elections was limited or was not visibly seen like the post 2018 elections which saw the army opening fire on the protesters, killing six innocent civilians and injuring hundreds of others. The study conducted by Bratton and Masunungure (2018) on behalf of Afrobarometre, indicates that $71 \%$ of the Zimbabweans who participated on the survey do not support military rule and $68 \%$ believe military should be apolitical. The army got involved in the removal of Robert Mugabe and replacing him with a government which comprises of former military officers and ZANU Pf cadres (United States Institute of Peace, 2018). This relationship between the army and the ruling party compromises the existence of the army as an independent non-party institution. In the post 2018 elections the army was unleashed on the public and protesting citizens killing and beating people (Bratton \& Masunungure, 2018).

\section{The use of Police on Civilian}

Human Rights Watch (2009) note that during the 2008 elections war veterans and the ZANU PF youth were supported by the army and the police in committing aggressive acts against the opposition. This resulted in the killing of approximately 36 people and about 2000 MDC activists were arrested (Human Rights watch, 2009:1). Further, Human Rights Activists, journalists, civil society, and trade unionists were arrested on politically motivated charges. In more alignment to the predictions of "who-did-what-to-whom" criteria by Birch \& Muchlinski (2017) during the presidential elections run off 2008, at least"[...]100 chief election officers and election workers were arrested for fraud" (Human Rights Watch, 2009, p.142). Human Rights Watch (2009) study categorically highlights or records the beating of the late opposition leader, Morgan Tsvangirai and scores of MDC supporters by police.

These cases discussed under this type of electoral violence, highlighted by the "who-did-what-to-whom" criteria, the State-on-nonstate violence is really applicable to the Zimbabwean scenario, as the ruling party utilises various groups to commit violence on its behalf. The case studies reviewed here can therefore reveal that party youth, war veterans, police and the 
army can be important stakeholders in forging peaceful elections in the future of Zimbabwe.

\section{Electoral Violence Committed by Political Parties, Groups and Individuals}

This section reveals a lot of actors involved in electoral violence in Zimbabwe, under the "who-didwhat-to-whom" framework, this section falls under "nonstate-on-nonstate" (Birch \& Muchlinski, 2017). They are quite a number of actors involved who also perpetrate violence, who are revealed by this research. The most relevant group, it's called "Chipangano". This is a group of unemployed youth based in Harare high density suburb called Mbare. This group is known for its criminal activities, although the ruling party would not want to be associated with it (Moyo, 2011). However, the big Man in the ruling party use the group to assault members of the opposition. The Chipangano group was used to intimidate the urban population into voting for the ruling party (Moyo, 2011). In return, Chipangano group would gain opportunities to regulate or demand rent from traders who sell their products. Criminality was not regulated in this area, as both actors benefited from each other's existence (Moyo 2011). According to the survey results of the study conducted by Armed Conflict Location and Crisis (ACLED) between 1998 and 2018, it can reveal that most electoral violence committed was not by the state actors. This is illustrated bellow:

Table 3: Frequency of Actors against Events in Zimbabwe, 1998 to 2018

\begin{tabular}{|c|c|c|}
\hline & No. of events & \% of total \\
\hline \hline ZRP & 846 & 14.4 \\
\hline Militia & 97 & 1.7 \\
\hline War vets & 234 & 4.0 \\
\hline ZANU-PF & 2607 & 44.5 \\
\hline ZNA & 392 & 6.7 \\
\hline CIO & 91 & 1.6 \\
\hline MDC & 241 & 4.1 \\
\hline Protestor & 666 & 11.4 \\
\hline Rioters & 321 & 5.5 \\
\hline Other & 364 & 6.2 \\
\hline
\end{tabular}

Source: ACLED database in Research \& Advocacy Unit (2018: 4).

In this table the state actors namely, Central Intelligence Organization, Zimbabwe Republic Police and Zimbabwe National Army form only $22.77 \%$ of the perpetrators of violence. This support the argument of this paper that there are many stakeholders involved in electoral violence. On the contrary, even MDC supporters are also seen protesting and fighting with the police, prior to the release of the results.

\section{Application of the Political Stakeholder Framework to Electoral Violence Prevention}

This study also utilised political stakeholder engagement framework in trying to figure out how to combat electoral violence and make policy recommendations. The study adopted this framework to compliment the "who-did-what-to-whom" criteria by Birch \& Muchlinski (2017), as the study has revealed various actors who may or are the causes of electoral violence in Zimbabwe. In order to apply this framework, we used the current situation following the 2018, elections to elucidates on what can be the way forward for Zimbabwe. This section engages the tenets of the political stakeholder framework to electoral violence and its relevance to the Zimbabwean Scenario. The discussion continues below:

\section{Political Stakeholder Identification}

In this study, the definition which defines a political stakeholder as "an individual or group (political party) which has an interest or stake in the government or public affairs of a country and can affect, or be affected by, the achievements of the government or affairs of the country" (Akwei, 2018, p. 480). This allows us to see who should be included in the engagement process before and after the elections. The political stakeholder engagement framework shows that political parties and candidates form a key part of the process. This is more synonymous with what President Mnangagwa did recently when he called upon the political parties to come on board to have a dialogue (Rweba, 2019). What he failed to understand is the interest and influence of each stakeholder. All small parties and candidates came except the main opposition party, MDC (Rweba, 2019). The opposition questioned the sincerity of conducting dialogue when some of its members are in jail.

To correct this, one has to be in cognisant of three aspects suggested by Mitchel, Agle and Wood (1997) when they noticed that power, legitimacy and agency, should be considered key aspects when doing stakeholder analysis. It is important to think of scenario where $A$ who has power, to influence $B$; and that is something B would not do on their own (Mitchel et al., 1997). In terms of legitimacy, how a stakeholder is perceived in relation to the elections, are the actions of 
the stakeholder assumed to be desirable. The last aspect is agency, that is the degree to which the tentative stakeholder wants action. In the case of Zimbabwe, as we have noted in the earlier discussion, political parties, candidates, the state's agencies, the army, Central Intelligence Organisation and police; prominent human rights activist should be part of the stakeholders.

\section{Vision and Planning by Stakeholders}

To make the engagement process in Zimbabwe a success, it based literary on the attainment of the first aspect under the political stakeholder engagement framework, the ability to get relevant stakeholders to commit themselves to dialogue to be a part of the process. Scholars note that it is important to set a vision and objectives of the engagement process (Jeffree, 2009; Akwei, 2018). In Zimbabwe, this process has started but without any relevant stakeholders involved. This does not add to the successful implementation of the stakeholder engagement framework. However, in the present of all relevant stakeholders, visons and plans can be decided by all actors.

\section{Consultation, Implementation, Monitoring and Evaluation of Goals by Stakeholders}

This requires development of trust as each stakeholder will need to commit to the discussions during the consultations and this also works during the implementations. The working together of multiple political actors is not something new. It has been witnessed in countries like Malawi. In Malawi, multiparty liaison committees were established (Taylor, 2018). It consisted of district commissioners who chaired the committees, representatives from political parties, traditional authorities, local civil societies, clergies and clerks from the MEC (Taylor, 2018). The level engagement was high and so so was the success (Taylor, 2018). It should be noted that as different actors implement the agreed goals, the level of trust increases and so does the commitment.

\section{CONCLUSION}

The process of preventing electoral violence differs from one context to another. In Zimbabwe, as estimated by the popular theoretical approaches on the causes of electoral violence regarding the actors, it is indeed the autocratic government which preserves power through violence. The opposite is also true. The assumption that the opposition would also resort to violence when they lose elections is also true after analysing the 2018 elections. They also enjoy the cover of the international community based on the history of them being harassed by the ruling party. Their actions become more legitimate, with no one to question them. However, using the frame who-did-what-to whom we were able to identify a number of actors involved in electoral violence. The revealing of the different players helped me in my stakeholder engagement analysis, in trying to find who are the important actors to be involved as stakeholders. The Zimbabwean case study can reveal that the army and the police are critical stakeholders. This is due to the fact that they do not work for the state but influence how the ruling party functions and maintains its grip on power. The involvement of such state actors in the discussion with all relevant stakeholders about how the nation can mitigate electoral violence would be essential. The study proves that both frameworks then can be useful addition in the study of electoral violence. In light of this the study provides the following recommendations:

- Establishment of a multi-actor stakeholder engagement dialogue before and after elections. This would be helpful in establishing cooperation, commitment, trust and national values among the political stakeholders.

- Involvement of the army and police as independent actors during the multi-party stakeholder engagement dialogue as these two groups are important in safeguarding peace during elections and should be apolitical.

- Anti-electoral violence campaigns by multistakeholders which may comprise of traditional leaders, political parties, church, and Civil Society Organisation.

\section{REFERENCES}

Akwei, C. (2018). Mitigating Election Violence and Intimidation: Political Stakeholder Engagement Approach. Politics \& Policy, 46(3), 472-504. https://doi.org/10.1111/polp.12256

Bhasin, T. \&Ghandi, J. (2013). Timing and Targeting of State Repression in Authoritarian Elections, Electoral Studies,32.4 620-31. https://doi.org/10.1016/j.electstud.2013.07.011

Birch, S., \& Muchlinski, D. (2017). The Dataset of Countries at Risk of Electoral Violence. Terrorism and Political Violence, 1-20. https://doi.org/10.4324/9781315315126-6

Bondarouk, T., \& Ruel, H. (2004). Discourse analysis: making complex methodology simple. ECIS 2004 Proceedings, 1. Retrieved from http://aisel.aisnet.org/ecis2004/1

Bratton, M., \& Masunungure, E. V. (2018). Public Attitudes toward Zimbabwe's 2018 Elections: Downbeat yet Hopeful?. Cape Town:Afrobarometre 
Collier, P., \& Vicente, P. C. (2012). Violence, bribery, and fraud: the political economy of elections in Sub-Saharan Africa. Public choice, 153(1-2), 117-147. https://doi.org/10.1007/s11127-011-9777-z

Collier, P., and Vicente, P.C. (2008). Votes and Violence: Experimental Evidence from a Nigerian Election, Working Paper, Oxford: University of Oxford.

Fischer, J. ( 2002). 'Electoral Conflict and Violence: A Strategy for Study and Prevention', International Foundation for Election Systems, White Paper. Retrieved from http://www.ifes.org/publicationsdetail.html.

Hodzi, O. (2014). The youth factor in Zimbabwe's 2013 harmonised elections. Journal of African Elections, 13(2), 48-70. https://doi.org/10.20940/JAE/2014/v13i2a3

Höglund, K. (2009). Electoral violence in conflict-ridden societies: concepts, causes, and consequences. Terrorism and political violence, 21(3), 412-427. https://doi.org/10.1080/09546550902950290

Human Rights Watch. (2008). "Bullets for Each of You" StateSponsored Violence since Zimbabwe's March 29 Elections. Retrieved from https://www.hrw.org/report/2008/06/09/ bullets-each-you/state-sponsored-violence-zimbabwesmarch-29-elections\#.

Jeffree, N. (2009) Stakeholder engagement: A road map to meaningful engagement. Retrieved from https://www.fundacionseres.org/lists/informes/attachments/11 18/stakeholder\%20engagement.pdf

Kagwanja, P. (2005). Zimbabwe's March 2005 Elections: Dangers and Opportunities. African Security Studies, 14(3), 4-18. https://doi.org/10.1080/10246029.2005.9627366

Kriger, N. (2005). ZANU (PF) strategies in general elections, 19802000: Discourse and coercion. African Affairs, 104(414), 134. https://doi.org/10.1093/afraf/adi016

Laakso, L. (2007). Insights into electoral violence in Africa. Votes, money and violence: political parties and elections in SubSaharan Africa, Foreign Affairs, 86(6), 224-252.

Lindberg, S. I. (2007). Institutionalization of party systems? Stability and fluidity among legislative parties in Africa's democracies. Government and Opposition, 42(2), 215-241. https://doi.org/10.1111/j.1477-7053.2007.00219.x

Makumbe, J. M. (2002). Zimbabwe's hijacked election. Journal of Democracy, 13(4), 87-101. https://doi.org/10.1353/jod.2002.0071

Mapuva, J. (2010). Militarisation of public institutions, flawed electoral processes and curtailed citizen participation: the case of Zimbabwe. The Journal of Legislative Studies, 16(4), 460475 https://doi.org/10.1080/13572334.2010.519456

Mitchell, R. K., Agle, B. R., \& Wood, D. J. (1997). Toward a theory of stakeholder identification and salience: Defining the principle of who and what really counts. Academy of management review, 22(4), 853-886. https://doi.org/10.5465/amr.1997.9711022105

Moyo, J. (2011). Zanu-PF's militia feeds on extortion. Mail and Guardian, November 1824
Onapajo, H. (2014). Violence and Votes in Nigeria: The Dominance of Incumbents in the use of violence to rig elections. Africa Spectrum, 49(2), 27-51. https://doi.org/10.1177/000203971404900202

Research and Advocacy Unity(RAU). (2018). Zimbabwe-Political Violence and Elections. Retrieved from http://researchandadvocacyunit.org/system/files/Zimbabwe\% 20political\%20violence\%20\%26\%20elections.

Rweba, R. (2019).MDC leaders denounce Mnangagwa's meeting with unknown political parties, liken it to Smith-Muzorewa deal. Retrieved from https://www.myzimbabwe.co.zw/ news/40322-mdc-leaders-denounce-mnangagwas-meetingwith-unknown-political-parties-liken-it-to-smith-muzorewadeal.html.

Schedler, A. (2010). Authoritarianism's last line of defense. Journal of Democracy, 21(1), 69-80. https://doi.org/10.1353/jod.0.0137

Skaperdas, S., \& Grofman, B. (1995). Modeling negative campaigning. American Political Science Review, 89(1), 4961. https://doi.org/10.2307/2083074

Sterck, O. (2015). Fighting for votes: theory and evidence on the causes of electoral violence. Oxford: University of Oxford

Straus, S. \& Taylor, C. (2012). Democratization and Electoral Violence in Sub-Saharan Africa, 1990-2008. In Bekoe, D. (ed.), Voting in Fear: Electoral Violence in Sub-Saharan Africa (pp. 15-38). Washington, DC: United States Institute of Peace Press.

Taylor, C. F., Pevehouse, J. C., \& Straus, S. (2017). Perils of pluralism: Electoral violence and incumbency in sub-Saharan Africa. Journal of Peace Research, 54(3), 397-411. https://doi.org/10.1177/0022343316687801

Taylor, D. 2018. Shared Security, shared elections: Best practices for the prevention of electoral violence. Retrieved fromhttps://reliefweb.int/sites/reliefweb.int/files/resources/Ele ctoral-violence-report-web-version.pdf.

Tirivangasi, H. M., Nyahunda, L., \& Rapanyane, M. B. (2020). A critical analysis of the prospects of transitional justice in postMugabe era. Journal of Nation-building \& Policy Studies, 4(2), 161-186. https://doi.org/10.31920/2516-3132/2020/v4n2a9

United States Institute of Peace. (2018). Retrieved from https://www.usip.org/publications/2018/08/after-voting-andviolence-whats-next-zimbabwe.

US Bureau of Democracy, Human Rights, and Labor. (2009) Country Reports on Human Rights Practices. Retrieved from https://www.state.gov/j/drl/rls/hrrpt/2008/af/119032.htm.

Wallsworth, G. (2015). Electoral violence: An empirical examination of existing theories. Retrieved from http://econ.msu.edu/ seminars/docs/ElectionViolenceJMP10_28.pdf

Wantchekon, L. (1999). On the nature of first democratic elections. Journal of Conflict Resolution, 43(2), 245-258. https://doi.org/10.1177/0022002799043002008

Wilkinson, S. (2004). Votes and Violence: Electoral Competition and Ethnic Riots in India.Cambridge: Cambridge University Press. https://doi.org/10.1017/CBO9780511510458

\section{https://doi.org/10.6000/1929-4409.2021.10.125}

(c) 2021 Tirivangasi et al.; Licensee Lifescience Global.

This is an open access article licensed under the terms of the Creative Commons Attribution Non-Commercial License (http://creativecommons.org/licenses/by-nc/3.0/) which permits unrestricted, non-commercial use, distribution and reproduction in any medium, provided the work is properly cited. 